\title{
Fan-shaped outlets
}

\author{
Professor, Dr B. HeliLstron \\ DIRECTOR OF THE INSTITUTION OF HYDRAULICS \\ THE ROYA NSTTUTE OF TECHNOLOGY, STOCKHOLM
}

Texte français, page 881

\begin{abstract}
Sicale model investigations on seven models (one main model, scale: 1/60, and sia supplementary models, scale: 1/180) of two flood-outlet canals, one on each side of a rock-fill dam. The downstream ends of both canals are $12 \mathrm{~m}$, above extreme high water level in the river. They are designed for a discharge of $5,500 \mathrm{cu} . \mathrm{m} / \mathrm{s}$ each. Development of arrangements enabling maximum reduction of agitation and consequent damage to bed or structures by water jets.
\end{abstract}

In many water power plants flood water is discharged through a canal constructed in one of the banks of the river. This is particularly the case with reference to earth or rock-fill dams where water cannot be discharged over the dam itself. Care must be taken to avoid serious erosion of the river bed, especially if the floodwater canal ends at a certain height above the water level of the river. The layout should be such that waves and surges are reduced to a minimum, so that neither the river banks nor structural works in the neighbourhood are adversely affected.

In the following, a short description is given of hydraulic model tests used for finding suitable means of discharging flood-water under the conditions mentioned above. The tests were carried out at the Institution of Hydraulies of the Royal Institute of Technology, Stockholm, Sweden (*).

\section{THE POWER PLANT}

The power plant dealt with in this paper will comprise an underground power station, excavated and built in the rock on the right bank of the river, and a rock-fill dam. On either side of the dam there will be a flood-outlet canal, each closed by two gates. During the period of construction the water will pass through two diversion tunnels, one in each bank, excavated in the rock beneath the flood-outlet canals, and the dam site will be protected by two coffer-

(*) Consulting Engineers for the Project have been Vattenbyggnadsbyran (VBB), Stockholm. dams, one upstream and one downstream, built right across the river.

The crest of the rock-fill dam will be situated

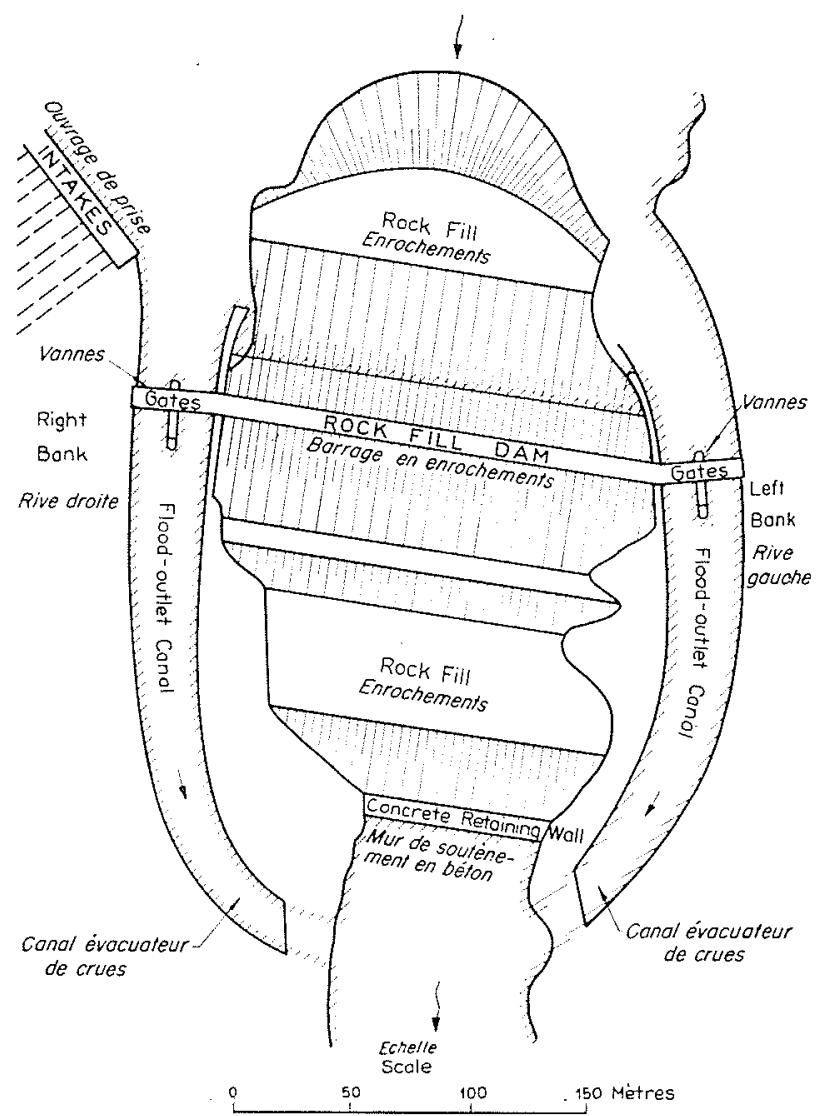

Fici. 1. General plan of dam and food-outlet canals, Proposal 1.

Fia. 1. - Vue générale du barrage et des cananx évacuateurs de crue, solntion 1. 


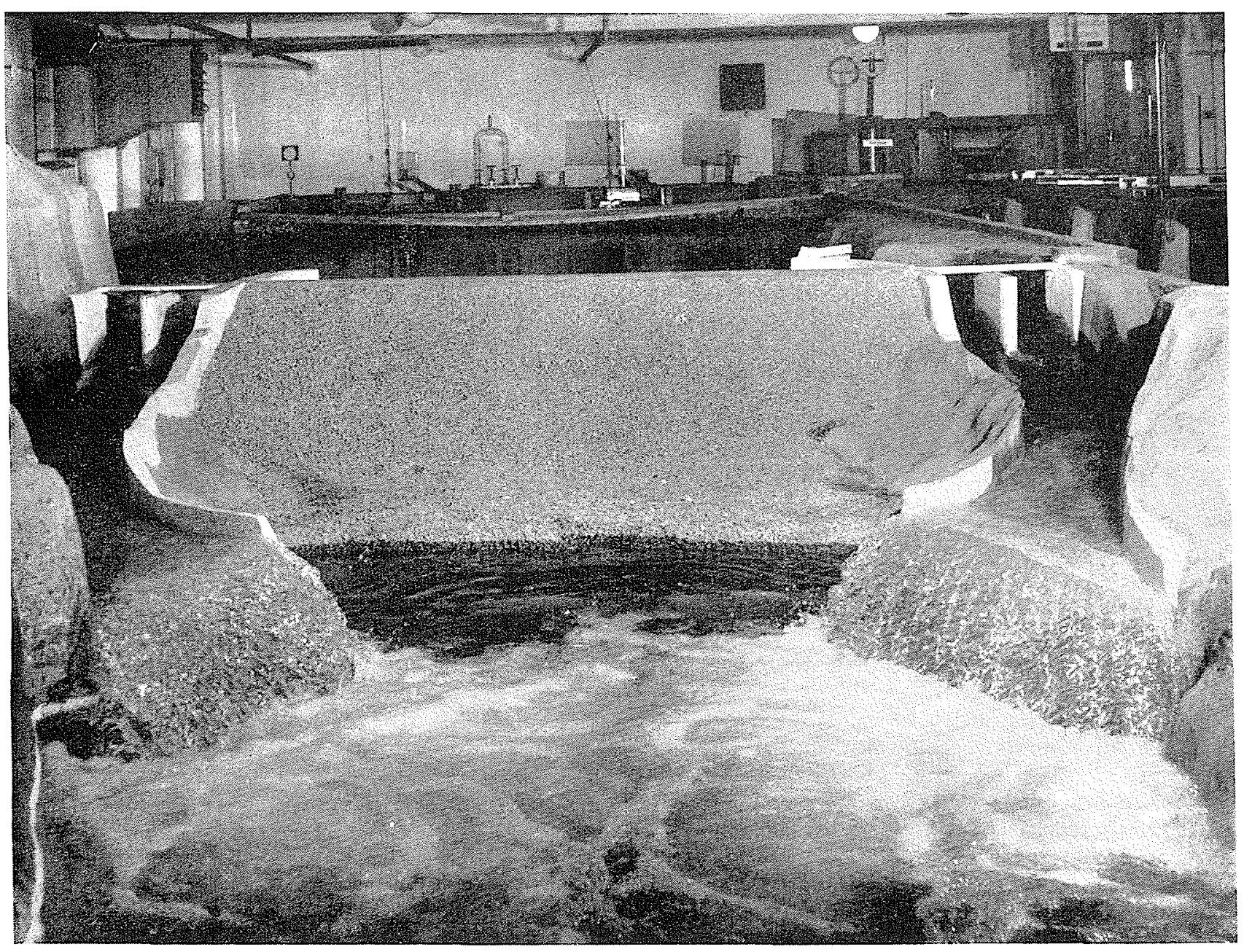

Fig. 2. - - Main model of Proposal 6, model scale 1: 60.

Fur. 2. - Modele d'ensemble pour solution 6; echelle: $1 / 60$.

about $70 \mathrm{~m}$ above the rock in the river bed. 'The maximum discharge through each canal is estimated at $5,500 \mathrm{~m}^{3} / \mathrm{s}$. The downstream parts of the canals will terminate at an elevation of $12 \mathrm{~m}$ above extreme high water level in the river. Hard rock in the river bed is situated about $28 \mathrm{~m}$ below extreme high water level.

A general plan of the plant is shown in Fig. 1, and Fig. 2 shows a photograph of the main model, looking upstream. In Fig. 1 the canals are shown as originally designed before the model tests were carried out, Proposal 1, whilst Fig. 2 shows the best shape of the canals as found from the tests, Proposal 6.

\section{Construction of the MOdels}

The main model was built to the scale of $1: 60$ and a separate study was made of the canals in six supplementary models, scale $1: 180$. The main model was at first constructed with canals built according to Proposal 1 and afterwards altered and fitted with canals built according to Proposal 6.

The surface contours of the main model were transferred from the contour maps of the dam site to masonite templates which were placed at a distance of $0.5 \mathrm{~m}$ apart on the level floor under the model area. The space between the templates was filled with sand, which was sprayed with water and packed and was used as a base for a $3 \mathrm{~cm}$ thick layer of rich cement mortar forming the surface of the model.

The intake to the power station and the concrete parts of the flood-outlets were made of wood and painted. The rock-fill dam was built of broken stone with a particle size up to $10 \mathrm{~mm}$ and had a water-tight core of brick, plastered with cement. 


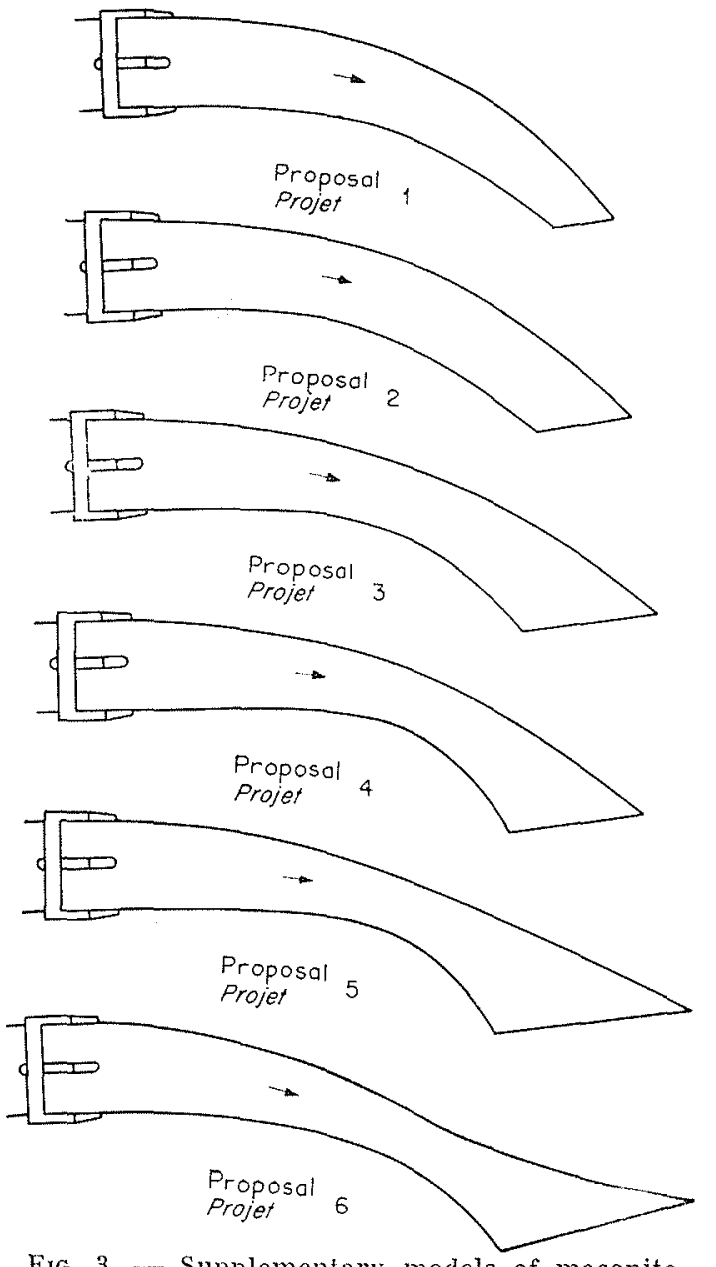

Fyc. 3. - Supplementary models of masonite of Proposals 1-6, model scale $1: 180$.

FIG.. 3. - Modèles particls en «masonite» pour solutions 1 a 6 ; ichelle : $1 / 180$.

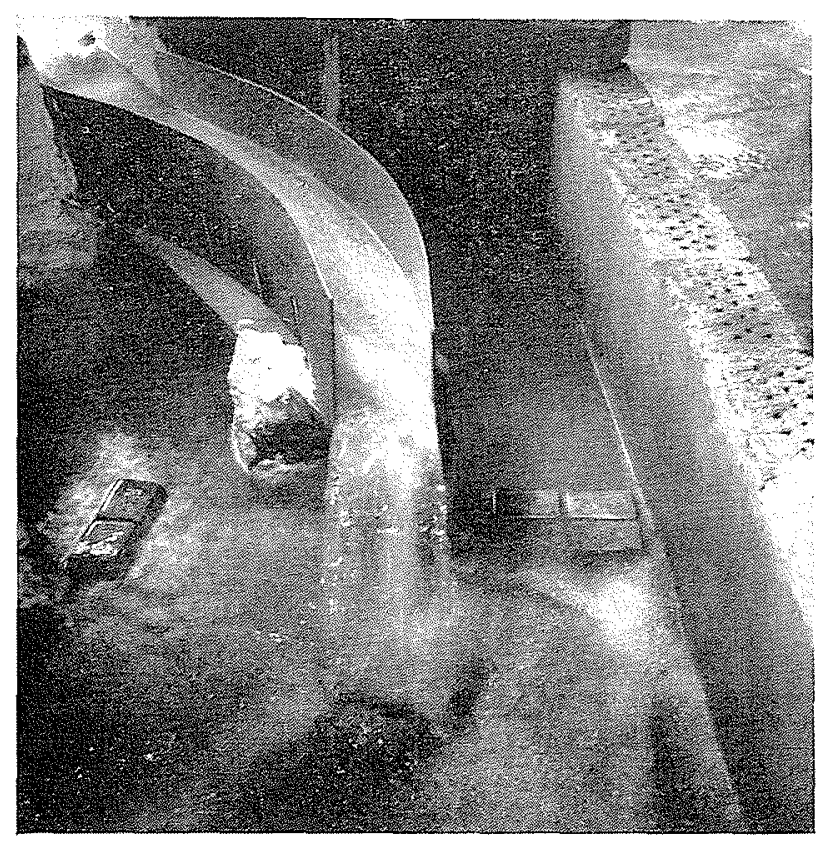

Fig. 4. - Flood-outlet canal, Proposal 1.

Fıa. 4. - Canal évacnateur de crue, solution 1.

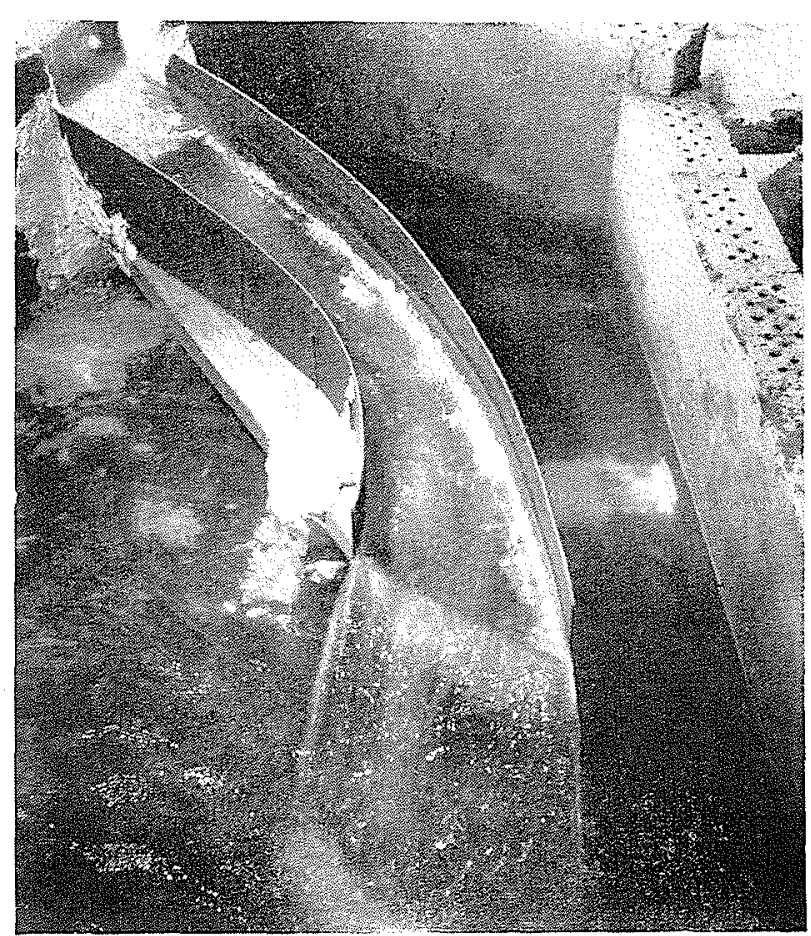

FIG. 5, - Flood-outlet canal, Proposal 3.

Frg. 5. - Canal évacuateur de crue, solution 3.

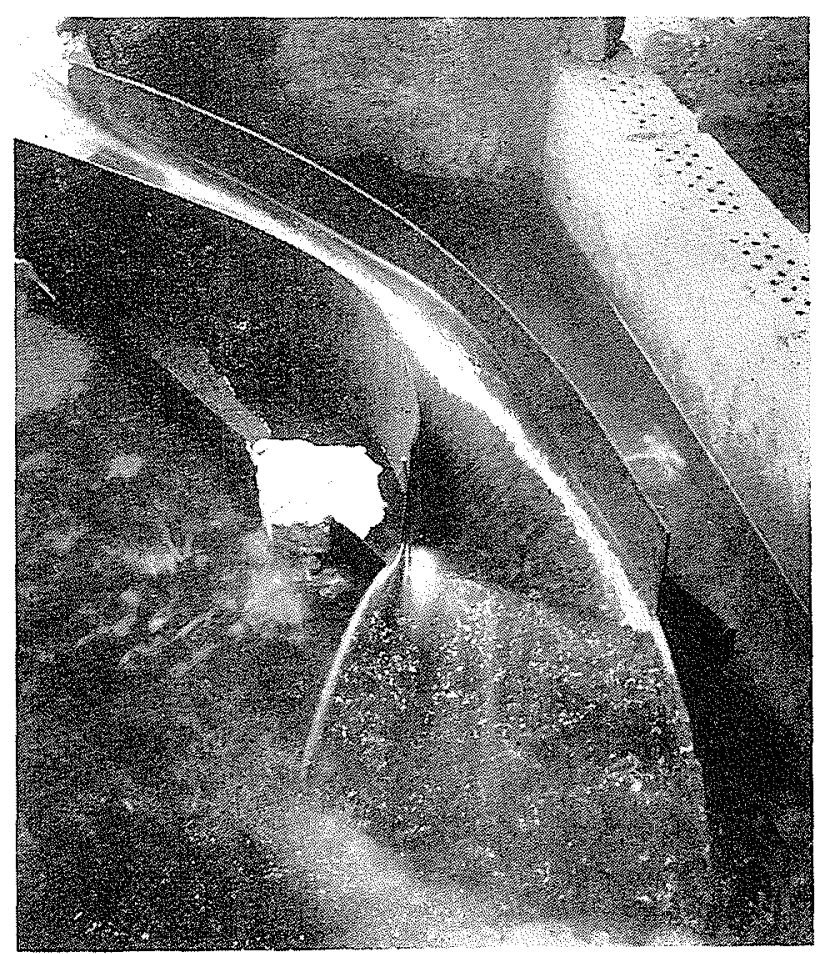

Fic. 6. - Flood-outlet canal, Proposal 4.

Fig. 6. - Canal évacuateur de crue, solution 4 . 


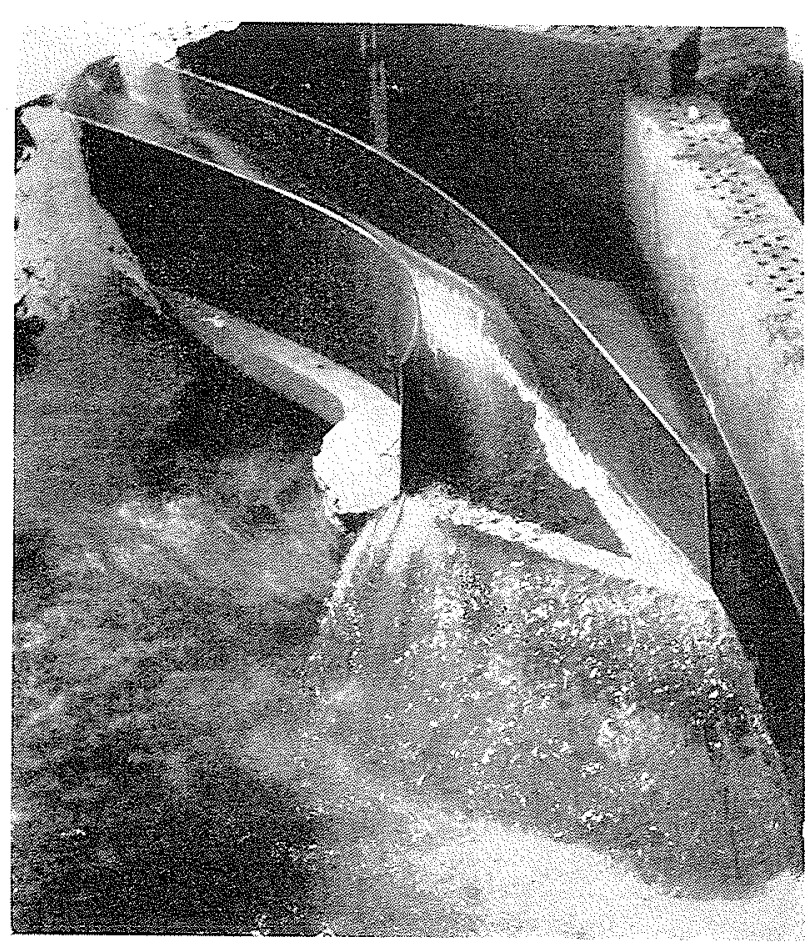

Fig. 7. - Flood-outret canal, Proposal 5.

Fag. 7. -- Canal évacuatenr de crue, solution 5.

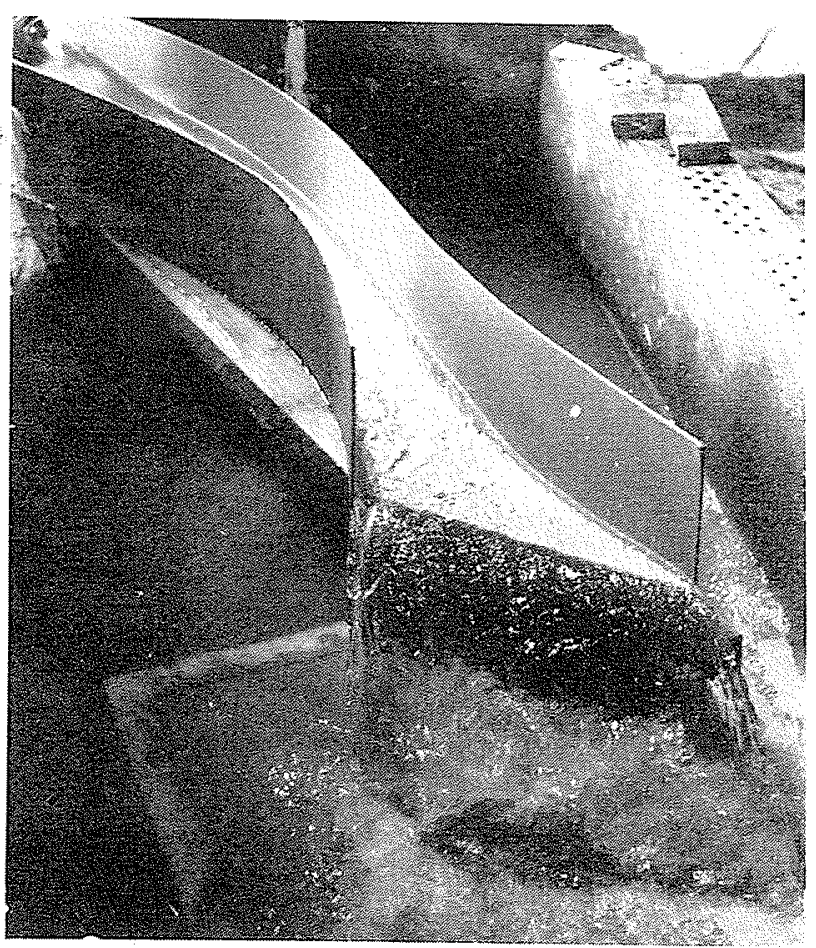

Fig. 8. - Flood-outlet canal, proposal 6.

Fia. 8. - Canal évacuateur de crue, solution 6
The six supplementary models were made of masonite.

Tests OF DIFFEREN'T MODELS

The six different designs were prepared in order to obtain, at the lowest cost, the most suitable means of discharging water into the river channel so that erosion of the river bed and production of surges would be reduced to a minimum.

In the first design, Proposal 1, the width of the flood-outlet canals was gradually decreased towards the outlet, the water jets emerging from

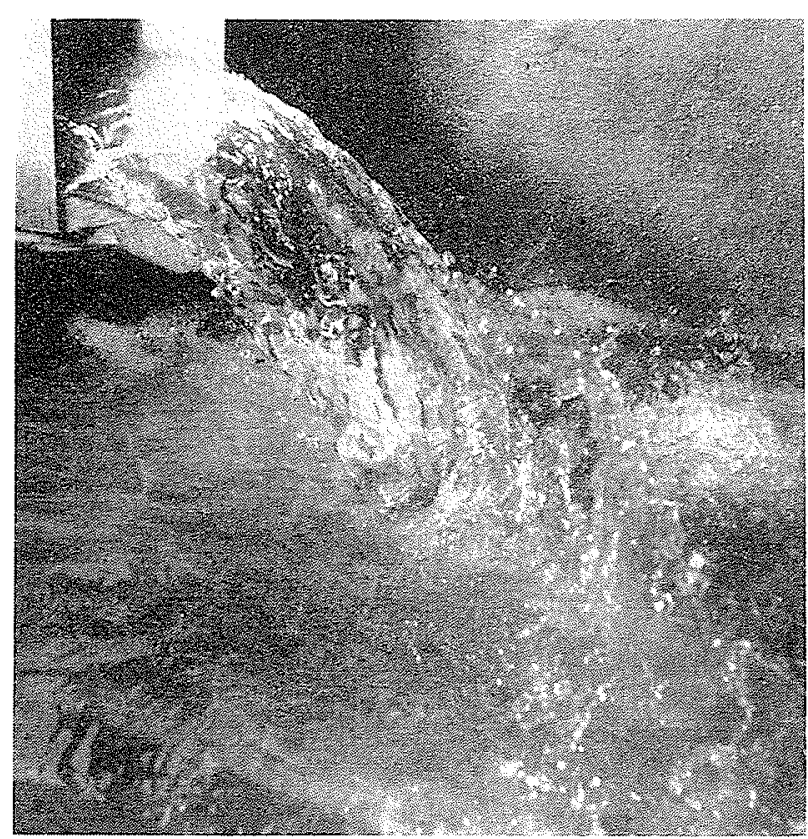

Fig. 9. - Proposal 1. The jet is almost as high as it is wide and is turning in the air.

Fig. 9. - Solution 1. La hanteur du jet est presque égalo à sa largeur et il foune dans l'air.

the canals having nearly the same height as width. The bottom of each canal at the downstream end was designed so that the water after leaving the canal turned round, thereby receiving an entrainment of air. The model tests, however, showed that when the water reached the river it was still a highly concentrated jet which was likely to cause considerable erosion. Since the angle of the jet was oblique to the direction of the river, the water hit the opposite bank with great force, especially when only one canal was functioning, and thus undesirable and high surges were set up in the river.

In order to avoid the above inconvenience, it 
Fig. 10, - Proposal 2. Owing

to the centrifugal

force the water surface is inclined and

is higher at the left side of the canal than at the right.

Fici. 10. - Solvirios 2. Par suite de la force centrifuge,

le nivean est plus élevé

le long de la paroi

rive gauche

que le long

de la paroi rine droite.
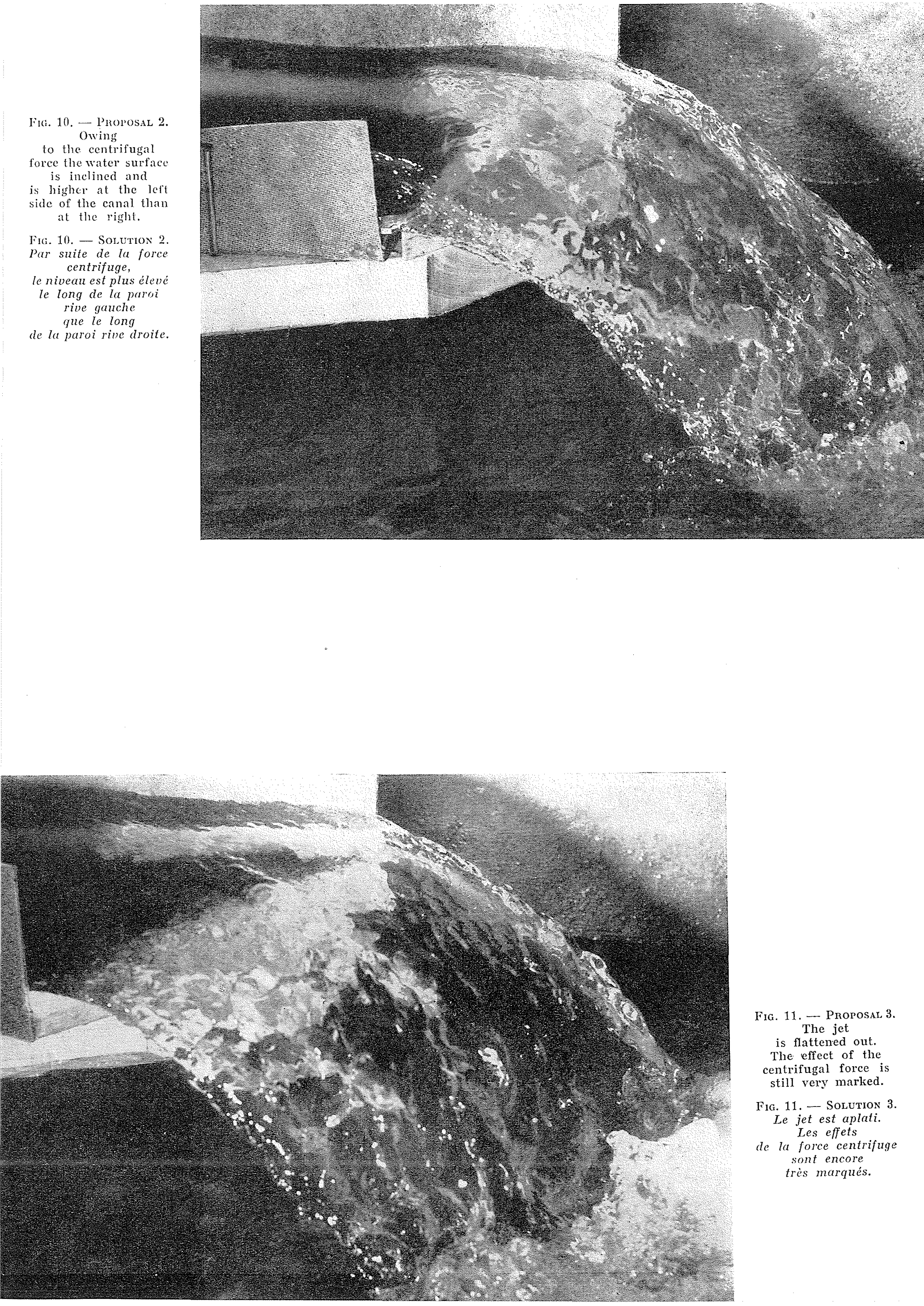

Fig. 11. - Proposal 3.

The jet

is flattened out. The effect of the centrifugal force is still very marked.

Fig. 11. - Solution 3. Le jet est aplati. Les effets

de la force centrifuge sont encore très marqués. 


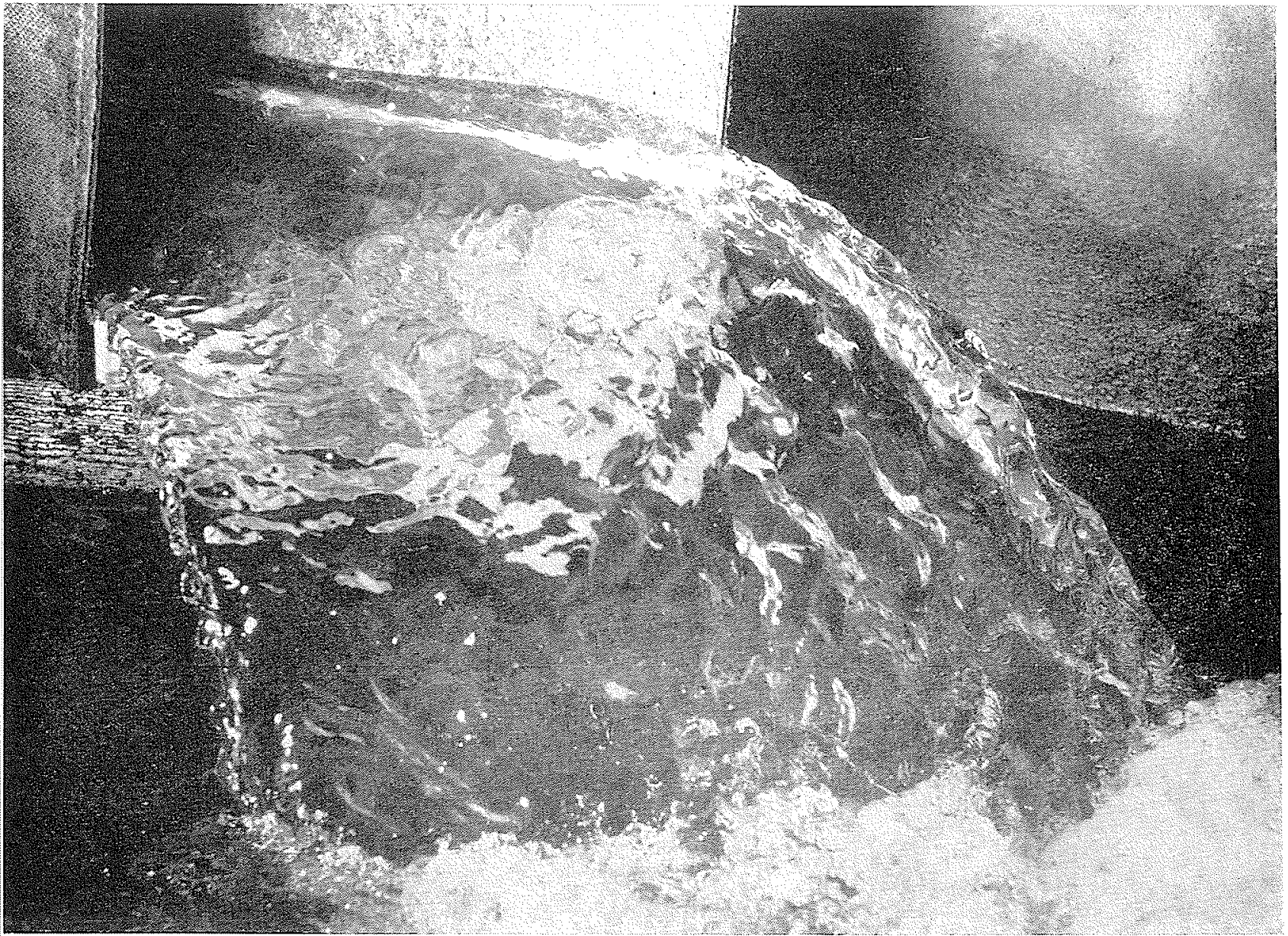

Fig. 12. - Phoposal An improvement in comparison witl Proposal 3.

Fig. 12. - Solution Amélioration par rapport $\dot{a}$ la solution 3

Fig. 13. - Proposal 5. The diffusor effect becomes noticeable.

Fig. 13. - Solutron 5. Les effets de diffusion commencent $\dot{a}$ se faire sentir.

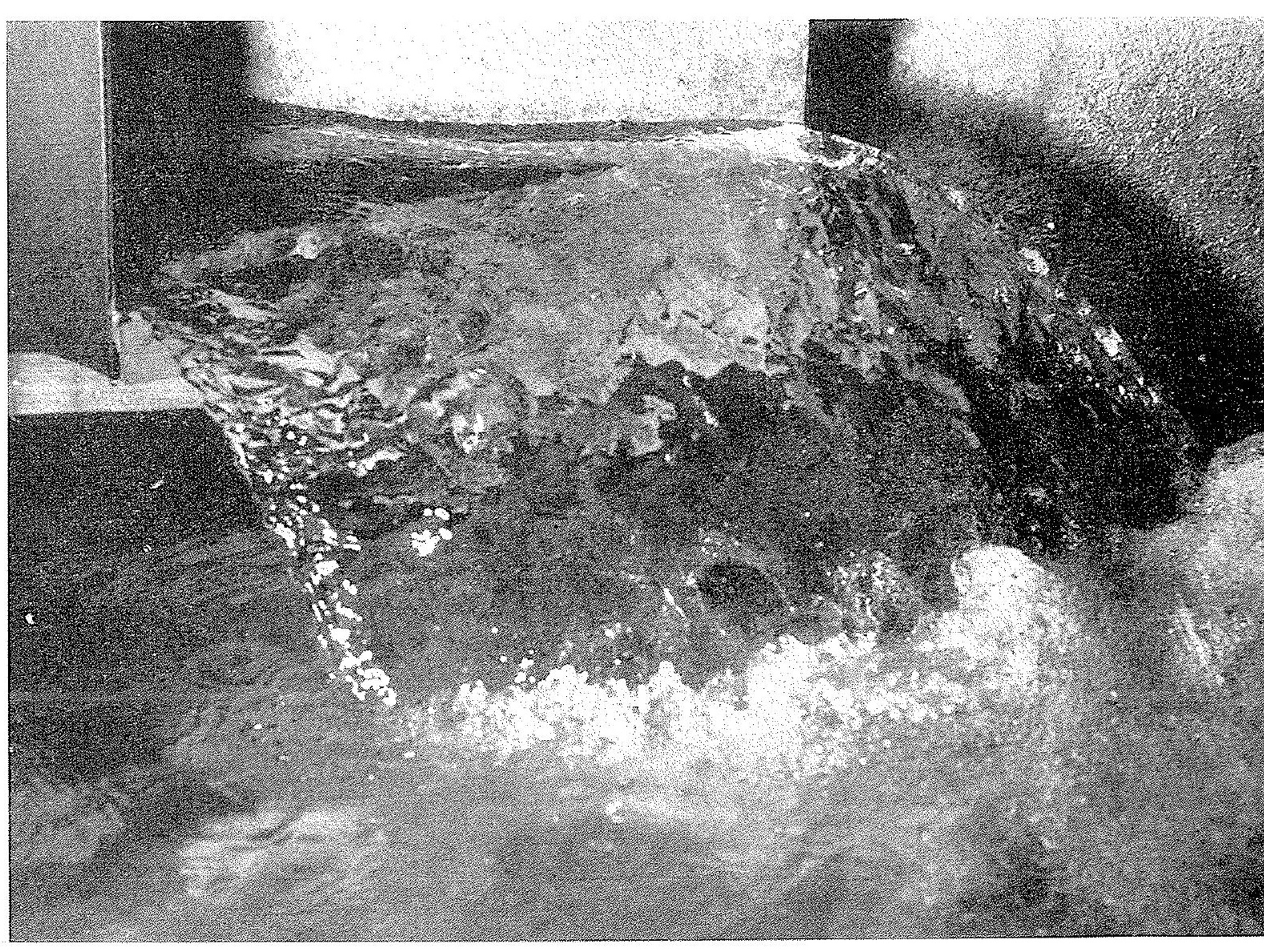


was decided to test a completely new shape of the flood-outlet canals. Instead of narrowing the downstream end to get concentrated water jets, the canals were successively widened and the downstream ends were given a fan-shaped design. This resulted in the water being distributed along a considerable stretch before being discharged back into the river, so that large quantities of air could be entrained. These factors would help to reduce the risk of erosion of the river bed.

Tests were carried out with five models of this type, Proposals 2 to 6 , built of masonite to the scale of $1: 180$, and a similar model was also made of Proposal 1, all models representing the left canal only, Fig. 3.

In Proposal 2 the downstream edge, nearly parallel to the river, was made almost twice as long as that in Proposal 1, and in Proposal 3 about two and a half times as long. Thus the downstream end of the canal acquired the shape of a diffusor, giving the jet a wide dispersion.

Proposal 4 differed from Proposal 3 mainly in that the canal was narrowed in the middle. This further emphasized the difrusor shape, and the dispersion of the jet became more pronounced.

In Proposal 5 the left side of the canal was straightened out from the downstream edge along a considerable distance upstream (about $1 / 3$ of the entire length of the canal). This resulted in the advantages of Proposal 4 being further increased.

In Proposal 6 the downstream part of the left side of the canal was bent outwards. This gave a satisfactory picture of the flow of water in the canal, and the form of the jet was particularly attractive. A general picture of the

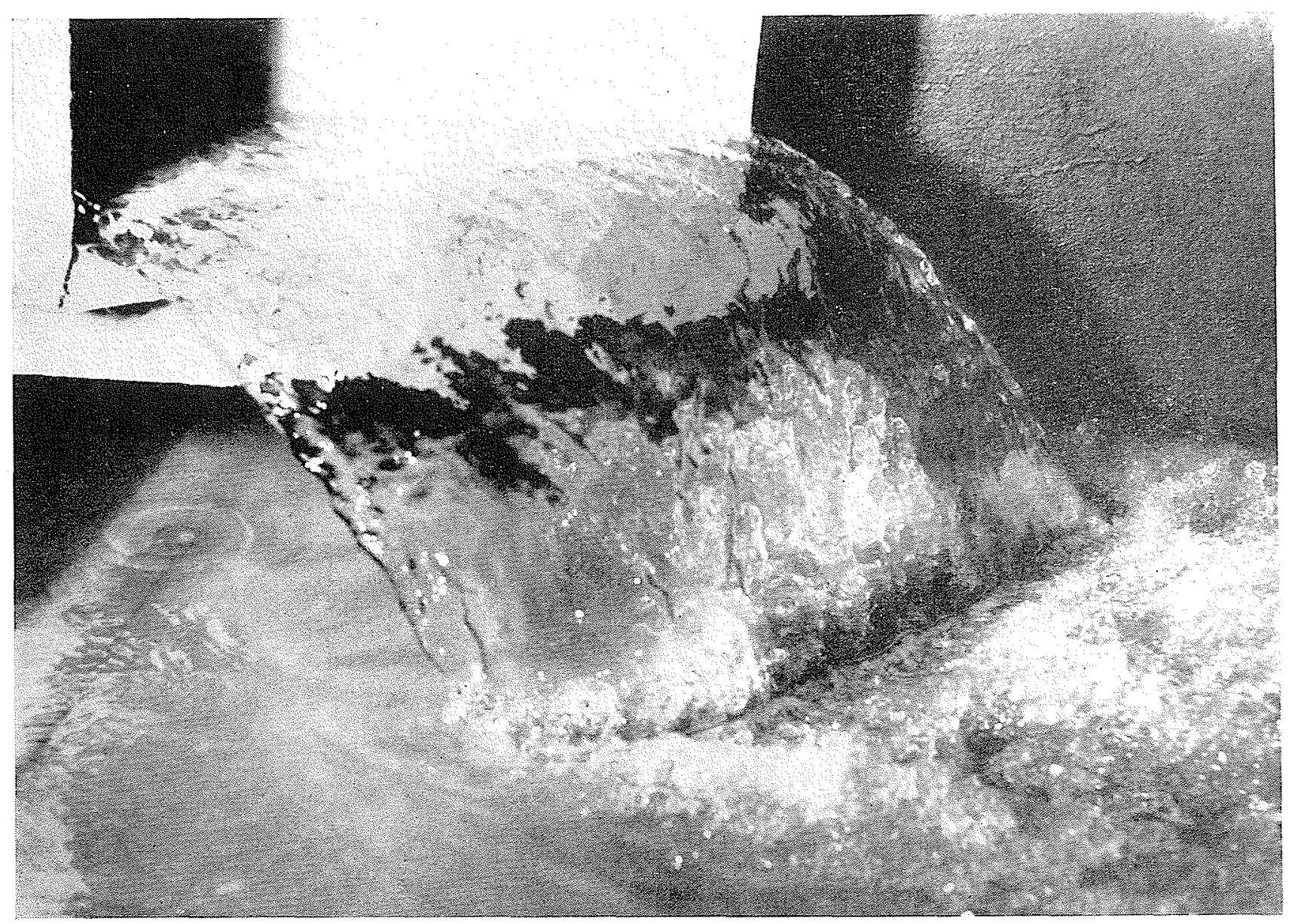

Fig. 14. - Proposal 6. - The diffusor effect is predominant, the jet being thin and wide, and much air becomes entrained in the river water, compare also fig. 2.

Fis. 14. - Solvtrox 6. - Les effets de diffusion prédominent. Le jet s'umincit, s'élargit ot entraine avec lui une quantité importante d'air. A comparer également avec fig. 2. 
flow in a number of canal models is shown in the photographs in Figs. 4 to 8, while the form of the jet at the downstream section of the canal in the various models is shown in Figs. 9 to 11.

After the completion of the tests on the supplementary models, Proposal 6 was incorporated in the main model to the scale of $1: 60$, Fig. 2.

It is difficult to study in a model the extent of the erosion of the rock at the place where the jet hits the river, but the erosive effect will obviously be greater when the jet is concentrated than when it is spread out. A considerably greater amount of air will be entrained when the jet is spread out over a wider area, and this will also tend to reduce erosion. As will be seen from Fig. 2, it was found in the model that a considerable quantity of air was entrained in the river water and that the surges in the river were insignificant.

The force with which the water struck against the banks was found to be considerably less in Proposal 6 than in Proposal 1.

An attempt to reduce the width of the canal still further than in the supplementary model of Proposal 6 gave negative results. The cross section then became too narrow and gave rise to a hydraulic jump.

In view of the above facts, Proposal 6 was considered to give the best means of discharging water from the flood-outlet eanals into the river.

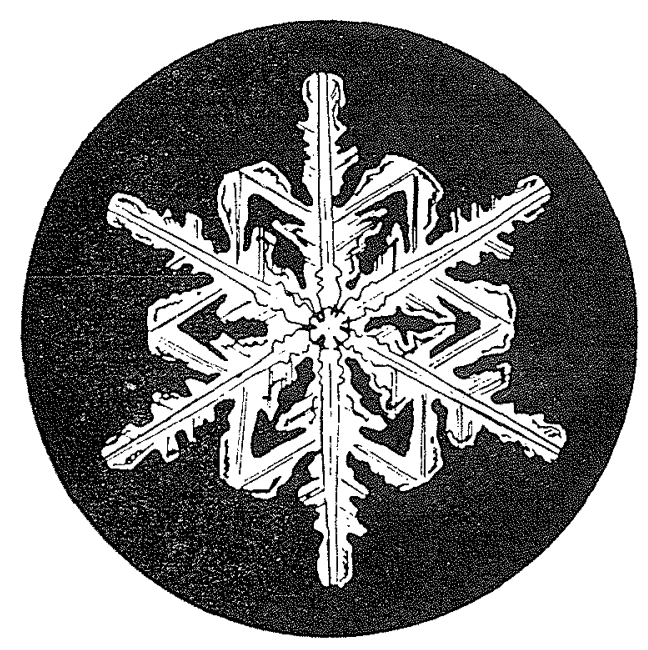




\title{
Evacuateurs de crue en éventails
}

\author{
PAR B. HELLSTROM

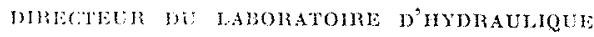

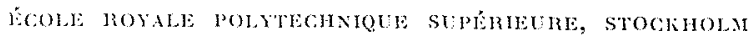

English text, page 873 .

\begin{abstract}
Elude sur modeles réduits (un modele d'ensenble au 1/60, 6 modiles partiels an 1/180) de deax cananx énacuatems de crue contonmant, chacun sur nne rive, un barrage en enrochements, et débonchant, à l'aval, $12 \mathrm{~m}$ au-dessus des plus harates eanx de ia rivière. Chaque
\end{abstract}

canal est pribu pont passer $5500 \mathrm{~m} 3 / \mathrm{s}$. Mise au point des dispositions permettant de réduire an maximum l'agilation et les dégradations résultanfes du lit ou des ombrages par les nappes déversantes.
Dans de nombreuses installations hydro-électriques les crues sont évacuées par un canal établi sur l'une des rives de la rivière. Ceci est tout particulièrement le cas lorsqu'il s'agit de barrages en terre ou en enrochement, dans lesquels l'eau ne peut pas déverser par-dessus le barrage lui-même. Il convient de prendre des précautions afin d'éviter une érosion grave du lit, surtout si le canal évacuateur débouche à une certaine hauteur audessus du niveau de la riviere: sa disposition doit viser à réduire le plus possible l'agitation, de facon à éviter d'endommager les rives de la riviere on les ouvrages voisins.

Dans ce qui suit, nous décrivons brièvement des essais sur modèle réduit destinés à mettre au point les dispositions d'un évacuateur de crue, fonction. nant dans les conditions ci-dessus. Ces essais ont dié effectues an Laboratoire d'Hydranlique de l'Ecole Royale Polytechnicue Supérieure de Stockholm, en Suède (*).

\section{Liss Ovvraks}

Les onvages, dont il est question ici, comporteront une centrale sonterraine creusée et aménagée dans le rocher sur la rive droite de la rivière, et un barrage en enrochement. A chacune de ses extremités le barrage sera contoumé par un canal evacuateur de crue fermé par deux vames. Pendant les travaux les eaux passeront par deux galerics de derivation, une dans chaque rive, creusées dans le rocher en dessous du canal évacnateur, l'emplacement du barrage étant protégé par deux batardeaux établis en travers de la rivière. l'un à l'amont ef l'autre à l'aval. Ia crete du bar-

(*) Les Ingénieurs Conseils de ce projet sont Vattenbyggnadsbyran (VBB), Stochholm. rage en enrochement se trouvera environ $70 \mathrm{~m}$ audessus du fond rocheux de la rivière. Le débit naxinum devant emprunter chacun des canaux est estimé à $5.500 \mathrm{~m}^{3} / \mathrm{s}$; à leur extrémité aval ces canaux se trouveront à $12 \mathrm{~m}$ au-dessus du niveau des plus hautes eaux de la rivière. Le rocher en place dans le lit de la rivière se trouve environ $28 \mathrm{~m}$ au-dessous du niveau des plus hautes eaux. La figure $1\left(^{* *}\right)$ donne le plan général des installations, et la figure 2 est une photographie du modèle d'ensemble vu vers l'amont. La figure 1 donne la disposition des canaux telle qu'elle avait été prévue avant les essais (projet 1) tandis que, sur la figure 2, ces canaux ont la forme mise au point d'après les essais (projet 6 ).

\section{Construction DU MODĖLE}

Le modèle principal a été réalisé à l'échelle du $1 / 60^{\circ}$ tandis que 6 modèles complémentaires au $1 / 180^{\circ}$ étaient destinés à faire une étude séparée des canaux. Le modèle principal fut d'abord réalisé avec les canaux tels qu'ils avaient été prévus au projet 1 , puis, par la suite, le modèle fut retouché et mis au point suivant la disposition du modèle 6 .

Le modelé du modèle principal fut réalisé en se basant sur la carte en courbe de niveau du site à partir de gabarits en bois traité (Masonite) disposés de 50 en $50 \mathrm{~cm}$ sur la plateforme supportant le modèle. L'espace compris entre ces gabarits fut rempli de sable, lequel ayant été arrosé d'eau et tassé servit de support à une couche de $3 \mathrm{~cm}$ d'un enduit très riche en ciment constituant la surface du modèle.

La prise d'eau alimentant la Centrale et les par-

${ }^{* *}$ Pour les figures, se reporter au texte anglais, p. 873 . 
lies en béton des évacuateurs de crue furent construites en bois et peintes. Le barrage en emrochement fut réalisé avec des pierres concassées jusqu'au calibre de $10 \mathrm{~mm}$; il comportait un noyau étanche fait de brique pilee et de ciment.

Les 6 modèles complémentaires furent réalisés en bois traité (Masonite).

\section{ESSAIS SUR LES DIFERENTS MODELES}

Chacun des 6 projets furent mis au point avec l'intention d'obtenir, au moindre coût, les dispositions les mieux à même d'assurer le déversement dans la rivière, en réduisant au minimum l'érosion du lit et l'agitation.

Dans le projet 1, la largeur des canaux évacuateurs allait en diminuant graduellement vers l'aval, la nappe déversante étant approximativement aussi haute que large. Le radier de chacun des canaux, a l'extrémité aval, était disposé de telle sorte que la nappe, en abandonnant l'ouvrage, se retournait, provocuant ainsi un entrainement d'air. Les essais sur modèle montrèrent, cependant, que lorsqu'elle atteignait la rivière, la nappe, encore très ramassée, était à même de provoquer une érosion importante. Le jet étant dirigé obliquement par rapport a Ia direction de la rivière, l'eau frappait violemment la rive opposée, surtout lorsqu'un seul des canaux fonctionnait; il en résultait dans la rivière une très forte agitation difficilement acceptable.

En vue d'éviter ces inconvénients, il fut décidé d'essayer pour les canaux évacuateurs une forme entièrement nonvelle. Au lien de rétrécir l'extrémité aval pour réaliser des jets d'eau concentrés, les canaux furent peu à peu élargis, et leur extrémité aval réalisée en forme d'éventail. Avant de se déverser dans la rivière l'eau se trouvait ainsi étalée en une large nappe, si bien qu'elle pouvait entrainer une grande quantité d'air. Ces facteurs permettaient d'espérer une réduction des risques d'érosion du lit.

Les essais d'une telie disposition furent conduits sur 5 modèles (projets $2 \dot{a} 6$ ) construits en "Masonite " à l'échelle du $1 / 180^{\circ}$; un modèle similaire fut fait également du projet 1 , tous ces modèles représentant seulement le canal rive gauche (fig. 3).

Dans le projet 2, le seuil aval, à peu près parallèle à la rivière, était environ deux fois plus large que dans le projet 1 ; dans le projet 3 il était deux fois et demi plus large. Ainsi l'extrémité aval du canal prenait la forme d'un diffuseur assurant au jet une très large dispersion.

Le projet 4 différait du projet 3 principalement par un rétrécissement du canal en son milieu. Il en résultait encore une accentuation de la forme du diffuseur et la dispersion du jet se faisait plus prononcée.

Dans le projet 5 la paroi rive gauche du canal fut rendue rectiligne, depuis l'extrémité aval jusqu'assez loin en amont (environ $1 / 3$ de la longueur totale du canal); ceci permit encore d'accentuer les avantages du projet 4 .

Dans le projet $n^{\circ} 6$, la partie aval de la paroi rive gauche du canal fut infléchic vers l'extérieur. L'écoulement dans le canal présenta alors un aspect satisfaisant, et la forme du jet était particulièrement séduisante. Les figures 4 à 8 montrent l'allure générale do l'écoulement sur de nombreux modeles de canaux, tandis que les figures 9 à 14 permeltent de se rendre compte de la forme du jet dans la section aval du canal sur les divers modèles.

Une fois terminés les essais sur les modèles complémentaires, le projet 6 fut reporté sur le modèle principal à l'échelle du $1 / 60^{\circ}$ (fig. 2).

In est difficile, sur un modèle, de se rendre comple exactement de l'érosion du rocher en place lorscque le jet frappe la rivière; mais il est évident que la capacité d'érosion est plus grande lorsque le jet est concentré que lorsqu'il est dispersé. Le jet entraine d'autant plus d'air qu'il est plus largement étalé, ce qui tend aussi à réduire l'érosion. Comme on peut le voir sur la figure 2, le modèle montra qu'une grande quantité d'air était entrainée dans l'eau de la rivière dont l'agitation était insignifiante. La violence avec laquelle l'eau frappait les rives s'avéra bien moindre sur le projet 6 que sur le projet 1 .

Une tentative de réduire la largeur du canal encore davantage que dans le modèle complémentaire du projet 6 ne donna pas de résultat. La section devient alors trop étroite et donne naissance à un ressaut.

Compte tenu des observations ci-dessus, le projet 6 fut considéré comme correspondant aux meilleures conditions de restitution de l'eau depuis le canal évacuateur jusqu'à la rivière. 